\title{
The Implications Of Politeness Strategies Among Teachers And Students In The Classroom
}

\author{
Widiadnya, I Gusti Ngurah Bagus Yoga ${ }^{1}$, Seken, Ketut and Santosa, Made Hery
} Universitas Pendidikan Ganesha, Singaraja, Bali-Indonesia

\begin{abstract}
Politeness was needed to be implemented since rudeness creates conflict between teacher and students. Politeness also used in order to teach students the way of being polite, and redress the conflict in conversation. This study aimed at analyzing the implication of using politeness strategies on teaching and learning process. The subjects of this study were the tenth grade teacher and students of SMK Nusa Dua Bali. The data were in the form of conversations among the subjects in their interactions during the teaching and learning process in the classroom. The data were collected through observations and interview. The result of this study showed that, there were some implications of the politeness strategy employed by the teacher and students at SMK Nusa Dua, such as politeness created efficient teaching and learning process, respected communications between teacher and students. Besides that cooperation interaction between teacher and students were found improving, and less imposition and indirectness in teaching and learning process. Those implications motivate students and develop a meaningful teaching and learning process.
\end{abstract}

Key Words: Politeness Strategy, Teaching Learning Process

\section{Introduction}

Politeness in communication, courtesy, or etiquette is a procedure, custom, or custom prevailing in the society. The people live together in a society and do available conventions or norms in the social society where the politeness as a strategy to avoid conflict that might be happened and also in order to develop good relationship or togetherness in social interaction [8,9]. When talking about politeness in the communication, language will be as a behavior of human in the social interaction [4]. Means that politeness is rules of behavior which is agreed together by the society where it is applied. In the real life that is occurred in the society politeness that can be seen from the various facets of daily interaction. First, politeness contains the value of demonstrating good manners in daily interactions. When someone says something in a 
polite way to others, the hearer will consider that person is polite or not. When it has good values, the hearer will continue those manners, and vice versa. Second, politeness is very contextual; it is valid in a society, place, or a particular situation, but not necessarily applicable to other communities, place, or situations. Third, politeness is always bipolar, such as between children and parents, between young people and older people, between the hosts and guests, among men and women, between students and teachers, and so on. Fourth, politeness is reflected in the dress code (dress), how to do (acting), and how to speak (language) [9]. Based on those facets, the researcher put this attention to the implication of using politeness in the communication among students and teacher. As stated by [6], the use of appropriate politeness strategy will motivate the students. In other word, students have good spirit when they learn English in classroom

Politeness is relevant and important in education, such as in classroom teaching and learning practice. During the teaching and learning process the teacher uses many utterances to communicate with the students which show politeness strategy. Considering the politeness, it is consisted of strategy to make the politeness appropriate in a situation of communication among students and teachers. In a definite community like in classroom, politeness is needed to be implemented since rudeness creates conflict between teacher and students. It means that politeness is used in classroom interaction in order to build good relationship among teachers and students. By considering the politeness strategy in communication among students and teacher, it is obvious that discussing of implication of politeness strategy used by the students and teachers is important in the classroom interaction. The politeness strategy can be chosen as politeness behavior of the students by teacher or by the students to their teacher.

This research study aimed at analyzing the implication of politeness strategies that applied by students and the teacher in their interaction in the classroom. Furthermore, the researcher wants to analyze the implication of how does politeness strategies are use in teaching and learning process. Learning process is the main process in the school, when the teacher starts to use the polite utterance with the student in their interaction, it could give the student knowledge of how the politeness must be used in all the context of situation. It would change the student attitude when they make an interaction with other. SMK Nusa Dua Bali is the school that concerns about hospitality industry, so it means that the teacher and the students should have a good manner and attitude in communication. According to [5], politeness is a strategy used by the speaker to avoid conflict with the hearer. Besides, [2] groups the linguists' theories that have been introduced in the world. There are four categories of politeness theory. The first is politeness theory that believes with social norms. The second one is politeness theory that believes relationship or togetherness as a principle in a communication. The third type is politeness theory that believes about saving face. Then the fourth is politeness strategy that believes with conversational contract. This theory believes that all of participants have prepared the contract which is obtained the obligations. On the contrary, [7] claim that particular kind of act can threaten face, that is, the act that contras to what the face needs from the speaker. This is call face threatening act. In accordance to FTA, [10] gave the definition to face. According to Yule, face is the public self-image of a person. It refers to the emotional and social sense of self that everyone has and expects everyone else to recognize. Certain communicative acts might represent a threat on the face needs of interlocutors. FTA is seen as utterance or action that threatens person face. Some acts can threaten the hearers' negative face. Negative face is the desire of every competent adult member to have freedom of action, freedom of imposition, and not to be impeded by others. 
Furthermore, some others can threaten positive face of the hearer. Positive acts is the need of every member that his wants to be appreciated and accepted, to be treated as the member of the same group, and to know that his or her wants are shared by others. Basically, negative face as the basic claim to territories, personal preserves, right to non-distraction, such as: freedom from imposition, therefore, negative face emphasize other's rights and freedom. In the other hand, positive face as the positive consistent self-image or personally aimed at establishing strong ties between individuals. These to distinction of FTA may lead to do the FTA or not to do the FTA. The strategies of doing FTA depend on the circumstance whether the speaker wants to reserve the hearer face to any degree. In order to minimize the FTA, [7] presented an analysis strategy which lead to the theory of linguistic politeness. In line with the explanation above, it can be presented the politeness strategies to face the FTA's : Bald-on Record strategy usually do not attempt to minimize the threat to the hearer's face, although there are ways that bald on-record politeness can be use in trying to minimize facethreatening acts implicitly. Positive Politeness is tried to minimize the threat to the audience's positive face. Negative politeness involves expressing oneself appropriately in term of social distance and respecting status differences. Off-record, according to [4] do an FTA by off record means that the speaker conveys his FTA, by using indirect and ambiguous utterance. The researcher follows the theory from [7] as the main theory.

\section{Research Method}

The design of this research was descriptive qualitative research where all of aspect which related to the interaction between teacher and students involved and the strategy that related to the politeness were investigated in depth and explained in details. Descriptive-qualitative research was a research which investigated the quality of relationships, activities, situations, or materials [1]. The subject in this study was the tenth grade EFL teachers and the students of SMK Nusa Dua consisted of 5 classes and 2 teachers that taught in the grade tenth. The class divided into two course, hotel accommodation class and cookery class. For hotel accommodation class there were three classes namely class 10 AP1, 10 AP2, 10AP3 which consisted of 30 students in each class. Besides for cookery class there were two classes namely 10 TB1 and 10 TB2 which consisted of 35 students in each class. This study used non-participatory observation. It was based on the consideration that the researcher did not belong to the subject of the data. The researcher only took the role as the observer in the attempt of collecting the data. The data that collected in the form of conversation of the subject in their interaction during the teaching and learning process in the classroom collected through non-participants observation, where the researcher collected the data by recording the teaching and learning process as a video file, which have recorded by video camera or handy-cam and created the transcription of all the subjects' activities and utterances employed in the classroom interaction of tenth grade EFL students and teacher of SMK Nusa Dua. In addition, the researcher created a transcription from the video of teaching and learning process in order to analyze the utterances that containing the politeness strategy easier. The interview conducted directly to the tenth grade EFL teacher and student of SMK Nusa Dua. In the interview process was documented in the form of writing a notes and audio visual, this was done to support the valuable of the data obtain through observation of the video.

The researcher was the key point in conducting this qualitative research study. The researcher who was the informant that supported and developed another instrument of data collection in conducting this research study. The focus of the research defined 
clearly, and it might be possible for the researcher to develop other instruments which were expected to support and complement the data collection. So, the researcher had done the analysis of politeness strategy by [7] in classroom interaction that employed by the teacher and students. Thus, in conducting the observation in this research study, the researcher used video recorder to record the interaction that happened in teaching and learning process. The observation was focused on the theory from [7] where the criteria of each strategy of politeness have been stated, so that the utterances produced by teacher and students identified precisely. Besides, the implication here viewed from [3] theory. The observation conducted through the video recorder that helped the researcher to gain the occurrence of politeness strategies produced by teacher and students. Video record was a recording of both visual and audible components. Besides used video record, the researcher also used note to support the result of video record. Note was a brief record of something written down to assist the memory.

The analysis was conducted interactively and continuously in order to create the corpus data of the utterances in classroom interaction among teacher and students by following some steps. The first step was data analysis start as soon as the transcription was completed, and data analysis was administered in terms determining the politeness strategies and the implication. Second step was choosing the data which was needed to answer the research problems and throw out data which was not needed, identify the politeness implications. The last step, the data analysis was presented based on the research questions staging in order to get a good of the explanation of the implications of politeness strategies in this research study. The research questions were answered based on the information took basically from the linguistic behavior, especially the pragmatic aspect that focused on the implication of politeness strategies. Interpretation was based on the total context of the utterance under analysis. Based on the result the conclusion drawing was as the final activities. The conclusion was started to draw from the description of the data that obtained through analysis

\section{Results}

This present study found that there were some implications of using politeness strategies in teaching and learning process. The implications here were viewed from theory of [3] cooperative principle. First implication is efficient communication interaction in the process of teaching and learning. The teacher and students fulfill the efficient communication in teaching and learning in the term of interaction in communication by using bald on record as the strategy for creating the efficient communication in the classroom interaction for example,

(Selected example from data transcription 2)

Note:

$\mathrm{T}$

S

: Teacher

TD

: Student

\#

: Transcription Data

Teacher

: Number of Utterance

:Kemudian tadi tentang apa kesalahannya? Jalan - jalan. Jadi kalau kalian jalan-jalan bukan walking - walking tapi have a? 'Next, what is the mistake? 'jalan-jalan'. So, if you have a walk do not say walking walking, but have a? (T1; TD2; \#76)

Student

: walk. (S2; TD2; \#77) 
Teacher

: have a walk. Atau 'or' take a walk, jadi kamu sesuaikan kalau jalan-jalannya sudah berlalu 'have'nya jadi had, bentuk kedua have itu had.'Take'nya jadi? Verb duanya take apa? 'So you should adjust if you have a walk in the past, the word 'have' become 'had', the second form of have is had. The take become? Verb two of take is? (T1;TD2;\#78)

Student : Took. (S2; TD2; \#79)

Teacher : coba semuanya ucapkan 'take' 'Please all of you say take' (T1; TD2; \#80)

Students

: Take. (S2; TD2; \#81)

Teacher

: Lebih keras 'speak loudly' (T1; TD2; \#82)

Students

: Take (S2; TD2; \#83)

Teacher

: Bentuk duanya? 'The second form is?' (T1; TD2; \#84)

Students

: Took. (S2; TD2; \#85)

In that example, it could be seen that teacher gave the students a clue. By giving a clue the teacher guided the students to answer the desired answered. In this case the teacher tried to create the communication during teaching and learning process more efficient which can be proved by the condition where the students was able to get the teachers' wanted by guessing the clue. So politeness strategies made the teaching and learning process efficient.

The second implication was respect communication between teachers and students. Bald on record used by the teacher and students fulfill the respect behavior in their classroom interaction, for example:

(Selected example from data transcription 4)

Students : Good Afternoon. (S4; TD4; \#1)

Teacher : Good Afternoon, (T2; TD4; \#2)

From that example, the students and teacher used greeting, welcoming, and farewell. They expressed to respect behavior in order to create good relationship between teacher and students in classroom. Good relationship made good learning atmosphere in the process of teaching and learning. In this case, both of the teacher and the students should respect each other.

Third implication was cooperate interaction between teacher and students. In this case, the cooperation could be found in teaching and learning process, for example:

(Selected example from data transcription 5)

Teacher : Look at page 127, in your book. (T2; TD5; \#30)

Students : Okay. (Finding) (S5; TD5; \#31)

That example showed that teacher gave an instruction to the students then students looked responding the teachers' instruction. Teacher could design their instruction by choosing politeness strategies at the time; however, students also responded the teachers' instruction by choosing the strategy of politeness. In this case, politeness strategies created cooperation between teacher and students.

The last implication was less imposition in teaching and learning process. Teacher should be able to decrease imposition to students and also students should decrease imposition to the teacher. Less imposition was performed by using negative politeness. For example,

(Selected example from data transcription 1

Teacher : Silahkan dibaca dengan keras 'please, read loudly' (T1; TD1; \#26)

Teacher : : Ayo, baca sendiri aja. 'Come on, you just read it by yourself.

(T1; TD1; \#27

Students : : Baca sendiriya? 'read by myself?' (S1; TD1; \#28) 
Teacher $\quad$ : Baca sendiri aja 'just read by yourself" (T1; TD1; \#29)

From that example teacher used word 'aja' in order to minimize the imposition or intrinsic of the seriousness of the students. So, the students more relaxed in doing something or not to be imposed in doing something.

\section{Conclusion}

Based on the result of the data analysis and discussion, it could be drawn several conclusions that there were some implications of the politeness strategy that employed by the English as a foreign language teacher and students performed in four aspects where those aspects were very influential to the process teaching and learning, the four aspects such as efficient teaching and learning process, respect communication between teacher and students, cooperation interaction between teacher and students, less imposition and indirectness in teaching and learning process and togetherness between teacher and students. By implementing them in the teaching and learning process, it became meaningful and create a good atmosphere which all of the implication previously is much needed in the teaching and learning process of English as a foreign language classroom interaction.

\section{References}

1. Fraenkel, J. R. and Wallen (1993). How to Design and Evaluate Research in Education. New York: McGraw-Hill.

2. Fraser, B. (1990). Perspective on Politeness. Journal of Pragmatics, 3.

3. H. Grice, Logic and Conversation. In Leech, Principle of Pragmatics. (New York: Longman, 1975)

4. I K. Seken, Kesantunan Linguistik dan Pembelajaran Bahasa Kedua Naskah Orasi Pengenalan Jabatan Guru Besar Tetap Dalam Bidang Pendidikan Bahasa Inggris. (Singaraja: Ganesha University of Education, 2007)

5. Lakoff, R. (1973). The Logic of Politeness: or Minding your p's and q's. Chicago: Linguistics Society.

6. N. P. Carniasih, The Politeness at English Classroom Interaction and Its Implication Toward English Teaching-Learning in Wearnes Education Centre Bali (Denpasar: Udayana University, 2011)

7. P. Brown, S. C. Levinson, Politeness: Some Universals in Language Usages. (Cambridge: Cambridge University Press, 1987)

8. Rash, F. (2004). Linguistics Politeness and Greeting Rituals in German Speaking Switzerland. Journal of Curriculum and Supervision, 7.

9. R. Watts, Key Topics on Sociolinguistics Politeness. (Cambridge: Cambridge University Press, 2003)

10. ${ }_{10}$.Yule, G. (1996). Pragmatics. New York: Oxford University Press. 